\title{
Mitigation of Lead Stress in Triticum aestivum by Seed Priming in Aqueous Extracts of The Macroalgae Halimeda opuntia and Codium fragile
}

\author{
Afaf A. Nessem ${ }^{\#}$ and Rania A. El-shenody \\ Botany Department, Faculty of Science, Tanta University, Tanta, Egypt.
}

\begin{abstract}
THE MAJOR aim was to assess the effects of lead stress on Triticum aestivum (cv. Gemmeza R2) and to evaluate the role of seed priming in the aqueous extract of Halimeda opuntia or Codium fragile in the alleviation of these harmful effects. Seven days old T. aestivum seedlings growing from primed seeds were subjected to the sub-lethal concentration (400ppm) of lead nitrate $\left(\mathrm{Pb}\left(\mathrm{NO}_{3}\right)_{2}\right)$, then left to grow for 14 days. Results revealed that the lead nitrate significantly decreased root length, shoot height and fresh and dry masses of root and shoot, the content of $\mathrm{N}, \mathrm{PO}_{4}, \mathrm{~K}, \mathrm{Mg}, \mathrm{Ca}$ and $\mathrm{Cu}$, photosynthetic pigments ( $\mathrm{Chl} \mathrm{a}, \mathrm{Chl} \mathrm{b}$ ), total chlorophyll and photosynthetic activity of 21-days-old plants. On the other hand, carotenoid contents, total soluble sugars, $\mathrm{Na}$ and $\mathrm{Fe}$ content, the activities of catalase and peroxidase, ascorbic acid and malondialdehyde increased in leaves. The bioactive components in H. opuntia and C. fragile extracts such as minerals and phytohormones (auxins, cytokinins and gibberellins) could potentially participate in the alleviation of lead stress. Therefore, priming of $T$. aestivum seeds with the aqueous extracts of $H$. opuntia or $C$. fragile could mitigate all of the recorded harmful effects under lead stress.
\end{abstract}

Keywords: Lead stress, Triticum aestivum, Seaweeds, Photosynthesis, Antioxidants, Phytohormones.

\section{Introduction}

Wheat (Triticum aestivum L.) is a cereal crop belongs to family Poaceae. It is grown on $17 \%$ of all crop areas; it represents the stable food for $40 \%$ of the world's population and it is considered as the primary food in Africa (MacCaferri et al., 2009). The nutritional value of wheat is higher than maize and rice. Moreover, wheat is considered an essential component in Egyptian food (FAO, 2016).

Lead has a long residence time in soil due to its low solubility and strong binding capacity with soil colloids causing a large number of direct and indirect effects on plant growth and metabolism. These effects are including reduction in the length of roots and shoots, leaf area, the fresh and dry mass of both roots and shoots; decrease in the root hair development, water potential, plant hormones and stunted growth in plants; reduction in the rates of photosynthesis and transpiration (Nareshkumar et al., 2014). Lead causes also oxidative stress in plants (Kaur et al., 2012). In addition, lead affects the absorption of calcium, phosphorus, potassium and magnesium by polluted plants as it dramatically affects the permeability of plasma membranes to these elements resulting in nutrient imbalance (Yassen et al., 2007).

Seaweeds resources used to improve the harvest quantity and quality in agriculture. The use of seaweed products improves seeds germination, seedlings development, increases plant tolerance to environmental stresses and enhances plant growth and yield (Kumari et al., 2011).

Liquid extracts of seaweeds have gained importance as foliar sprays and soil drench for many crops to stimulate seedling germination and rooting (Anisimov et al., 2013). Algal extracts increased the functional activity of photosynthetic apparatus and leaf gas exchange; raise the contents of total carbohydrates, starch, amino acids and protein; enhanced the polyphenol content and antioxidant enzymes; increased the uptake and accumulation of nitrogen, phosphorus, potassium, sulphur, calcium, magnesium, iron, manganese, zinc and the ratio of $\mathrm{K} / \mathrm{Na}$, in addition to proline (Karanatsidis \& Berova, 2009). Organic fertilizers

"Corresponding author email: afaf_nessim@yahoo.com 
positively reduce the levels of lead and cadmium in plants as well as conductivity of soil but raised its pH (Abdalla \& El-Khoshiban, 2012).

Therefore, the aim of this study was to evaluate the harmful effect of lead stress on the growth and metabolic activities of Triticum aestivum plants and to study the role of presoaking of the seeds in aqueous extract of Halimeda opuntia or Codium fragile in the amelioration of these harmful effects.

\section{Materials and Methods}

\section{Plant materials}

Seeds of Triticum aestivum (cv. Gemmeza R2) were supplied by the Agricultural Research Center, Giza, Egypt, and was selected for apparent uniformity of size and shape.

\section{Algal collection and extract preparation}

Green seaweed, Halimeda opuntia and Codium fragile were collected during autumn (April, 2015), from Red Sea coast, Safaga, Egypt. Mangrove is situated about $17 \mathrm{~km}$ south Safaga City (Pristine station) (N 24 39'; E 35 6') and they were identified according to Aleem (1978), Abbott \& Hollenberg (1976) and Taylor (1985). Samples were brought to laboratory in polythene bags immerged in seawater, then, washed several times with fresh water and finally with distilled water. The samples were then air- dried, cut into small pieces and powdered in a mixer grinder. The powdered material was subjected to water extraction $\left(10 \mathrm{~g} / 200 \mathrm{ml}\right.$ dis. $\left.\mathrm{H}_{2} \mathrm{O}\right)$ in a water bath $\left(60^{\circ} \mathrm{C}\right)$ for $45 \mathrm{~min}$., then filtered using Whatman No. 1 filter paper to obtain $100 \%$ algal extract and stored at $4{ }^{\circ} \mathrm{C}$ for further analysis and treatments according to Anisimov \& Chaikina (2014).

\section{Hormonal analysis of algal extracts}

The hormonal content of Halimeda opuntia and Codium fragile aqueous extracts was analyzed according to Shindy \& Smith (1975). The different aqueous phases were prepared for GLC determination of the acidic hormones as auxin (IAA), gibberellins (GAs) and cytokinins. Computer controlled GLC-MS analyses of TMS (trimethylsilyl) derivatives of authentic standards or extract fractions were carried out with a Systems 150 output control module on a Finnigan mass spectrometer (Model 1015C) interfaced to a Varian Aerograph GLC (Model1400) fitted with a Goelke all-glass separator. Retention time and temperature for each peak were recorded and compared to those of TMS derivatives of authentic standards. Chromatography of unknowns and standards was also done to facilitate identification.

\section{Mineral content of algal extracts}

The mixed acid digestion method was used for elements determination $\left(\mathrm{Ca}^{+2}, \mathrm{Mg}^{+}, \mathrm{K}^{+}, \mathrm{N}\right.$, $\mathrm{Na}^{+}, \mathrm{Cl}^{-}, \mathrm{S}, \mathrm{Zn}, \mathrm{Fe}$ and $\mathrm{P}$ ) according to Allen et al. (1974). The measurements were carried out using the Atomic Absorption flame emission Spectrophotometer (Model Perkin Elmer 2380 Atomic Absorption Spectrophotometer).

\section{Experimental design}

A preliminary experiment was carried out using several concentrations (100, 200, 400 and $800 \mathrm{ppm})$ of lead nitrate $\left(\mathrm{Pb}\left(\mathrm{NO}_{3}\right)_{2}\right)$ to determine the sub-lethal concentration on wheat (Triticum aestivum L.) seeds during seedling stage, and it was found to be $400 \mathrm{ppm}$.

Wheat (Triticum aestivum) seeds (cv. Gemmeza R2) were selected for apparent uniformity of size and shape. Four groups of pots were prepared, each group was represented by five plastic pots $(25 \mathrm{~cm}$ diameter and $30 \mathrm{~cm}$ depth) and each one contained $5 \mathrm{~kg}$ clay-sandy soil (1:2 $\mathrm{w} / \mathrm{w})$. Ten seeds of wheat were sown in every pot. Each group represented one treatment. The first and second groups of seeds were primed in tap water (control), the third and fourth groups were primed with the aqueous extract of Halimeda opuntia and Codium fragile, respectively, all were primed for $3 \mathrm{~h}$, then they were sown, left to germinate for 7-days and then treated with $\left.\mathrm{Pb}\left(\mathrm{NO}_{3}\right)_{2}\right)$ solution $(400 \mathrm{ppm})$. Seeds were left to grow at $16 / 8 \mathrm{~h}$, at $25^{\circ} \mathrm{C} / 15^{\circ} \mathrm{C} \pm 2$, day/night and relative humidity of $65 \%$ and irrigated with tap water once daily for three days, then twice weekly for 18 days.

Samples were collected at 21-days old. Some growth criteria as root depth, shoot height, fresh and dry weights of roots and shoots and the photosynthetic pigments were determined for the fresh samples. Samples of fresh leaves were frozen immediately for determination of antioxidant enzyme activities, Ascorbate and malondialdehyde (MDA) contents. Some of the harvested samples were oven-dried at $50^{\circ} \mathrm{C}$ for determination of total soluble sugars and minerals analysis. 


\section{Physiological analyses}

Chlorophyll a \& b and carotenoids were determined following the method of Metzner et al. (1965) and expressed as mg. ${ }^{-1}$.f.wt. Total soluble carbohydrates were determined by the phenol-sulfuric acid method of Dubois et al. (1956) using glucose as a standard and expressed as $\mathrm{mg} \cdot \mathrm{g}^{-1} \cdot \mathrm{DW}$.

Lipid peroxidation was measured by determining the amount of malondialdehyde (MDA) as a product of peroxidation of unsaturated fatty acids, as described by Heath $\&$ Packer (1968) and expressed as ( $\mu$ mole. $\mathrm{g}^{-1}$ FW) and was calculated using the extinction coefficient $\left(155 \mathrm{mM}^{-1} \cdot \mathrm{cm}^{-1}\right)$.

Catalase [EC1.11.1.6] and peroxidase [EC1.11.1.7] were assayed according to Kato \& Shimizu (1987). Ascorbic acid was estimated according to Oser (1979).

The harvested samples were immediately blotted and oven-dried at $50^{\circ} \mathrm{C}$ for $24 \mathrm{~h}$ after they were washed with deionized water. Dried material was ground. Mixed acid digestion method was used for minerals determination according to Allen et al. (1974). The measurements of $\mathrm{Pb}$, $\mathrm{Ca}, \mathrm{Mg}, \mathrm{K}, \mathrm{N}, \mathrm{Na}, \mathrm{Fe}, \mathrm{Cu}$ and $\mathrm{PO}_{4}$ were carried out using the Atomic Absorption flame emission Spectrophotometer (Model Perkin Elmer 2380 Atomic Absorption Spectrophotometer).

\section{Statistical analysis}

Results were presented as the mean of three replicates \pm standard deviation (SD). Data obtained were analyzed statistically to determine the degree of significance using one-way analysis of variance (ANOVA) to determine the significance of difference using CoState (6.311) statistical software program under windows. Comparison of the main effects was performed using the Least Significance Difference (LSD) from the control.

\section{$\underline{\text { Results }}$}

Table 1 shows that the aqueous extract of Halimeda opuntia contained 228, 189.9 and $80.9 \mu \mathrm{g} / 100 \mathrm{ml}$ while Codium fragile contained $153,107.9$ and $45.8 \mu \mathrm{g} / 100 \mathrm{ml}$ for cytokinin, gibberellins and indole acetic acid (IAA), respectively.

Data in Table 2 shows the concentration of $\mathrm{Ca}, \mathrm{Mg}, \mathrm{Na}, \mathrm{K}, \mathrm{Fe}, \mathrm{P}, \mathrm{Cl}, \mathrm{S}$, and $\mathrm{Zn}$ in aqueous extract of $H$. opuntia was higher than in the aqueous extract of $C$. fragile.

Results in Fig. 1A reveal that lead stress caused a highly significant decrease in root length and shoot height of wheat plant, where the percentages of decrease were $36.2 \%$ and $31.2 \%$, respectively. On the other hand, priming of wheat seeds with the aqueous extracts of $H$. opuntia or C. fragile caused a highly significant increase in root length and shoot heights, where the percentages of increase were $12.4 \%$ and $8.6 \%$, respectively for root length and $2.7 \%$ and $0.63 \%$, respectively for shoot height.

Figure 1B shows that lead stress resulted in significant decreases in fresh weight of root and shoot of T. aestivum plants, where the percentages of decrease were $43.3 \%$ and $52.9 \%$, respectively. Similarly, results in Fig. 1C reveals that lead stress resulted in a highly significant decrease in dry weight of root and shoot, where the percentages were $43 \%$ and $46.3 \%$, respectively. The combined treatments of priming of wheat seeds with the aqueous extract of $H$. opuntia or C. fragile and lead stress alleviated this harmful effects of lead stress, where the fresh weight of root and shoot increased with a percentage of $16.3 \%$ and $8.3 \%$, respectively for root fresh weight and $10.9 \%$ and $9.2 \%$, respectively for shoot fresh weight. Moreover, priming with algal extracts could alleviate the toxic effect of lead stress by returning the values of root and shoot dry weights as those of control.

TABLE 1. Hormonal content of Halimeda opuntia and Codium fragile aqueous extracts.

\begin{tabular}{lcc}
\hline Hormones & Halimeda opuntia & Codium fragile \\
$(\boldsymbol{\mu g} / \mathbf{1 0 0} \mathbf{m l})$ & 228 & 153 \\
\hline Cytokinin & 189.9 & 107.9 \\
Gibberellins & 80.9 & 45.8 \\
Indole acetic acid & & \\
\hline
\end{tabular}


TABLE 2. Minerals content of the aqueous extracts of Halimeda opuntia and Codium fragile.

\begin{tabular}{lcc}
\hline Minerals content $(\mathbf{m g} / \mathbf{m l})$ & H. opuntia & C. fragile \\
\hline $\mathrm{Ca}$ & $122.85 \pm 0.7$ & $100.22 \pm 3.5$ \\
$\mathrm{Mg}$ & $100.7 \pm 0.98$ & $98.56 \pm 1.7$ \\
$\mathrm{Na}$ & $186.6 \pm 1.2$ & $180.26 \pm 3.4$ \\
$\mathrm{~K}$ & $138.2 \pm 2.2$ & $125.5 \pm 3.5$ \\
$\mathrm{Fe}$ & $0.89 \pm 0.005$ & $0.78 \pm 0.03$ \\
$\mathrm{P}$ & $11.5 \pm 0.87$ & $10.64 \pm 0.76$ \\
$\mathrm{Cl}$ & $210.3 \pm 1.3$ & $198.82 \pm 4.2$ \\
$\mathrm{~S}$ & $49.8 \pm 2.4$ & $45.2 \pm 2.7$ \\
$\mathrm{Zn}$ & $0.86 \pm 0.005$ & $0.75 \pm 0.021$ \\
$\mathrm{~N}_{2}$ & $10.82 \pm 0.12$ & $8.79 \pm 0.03$ \\
\hline
\end{tabular}
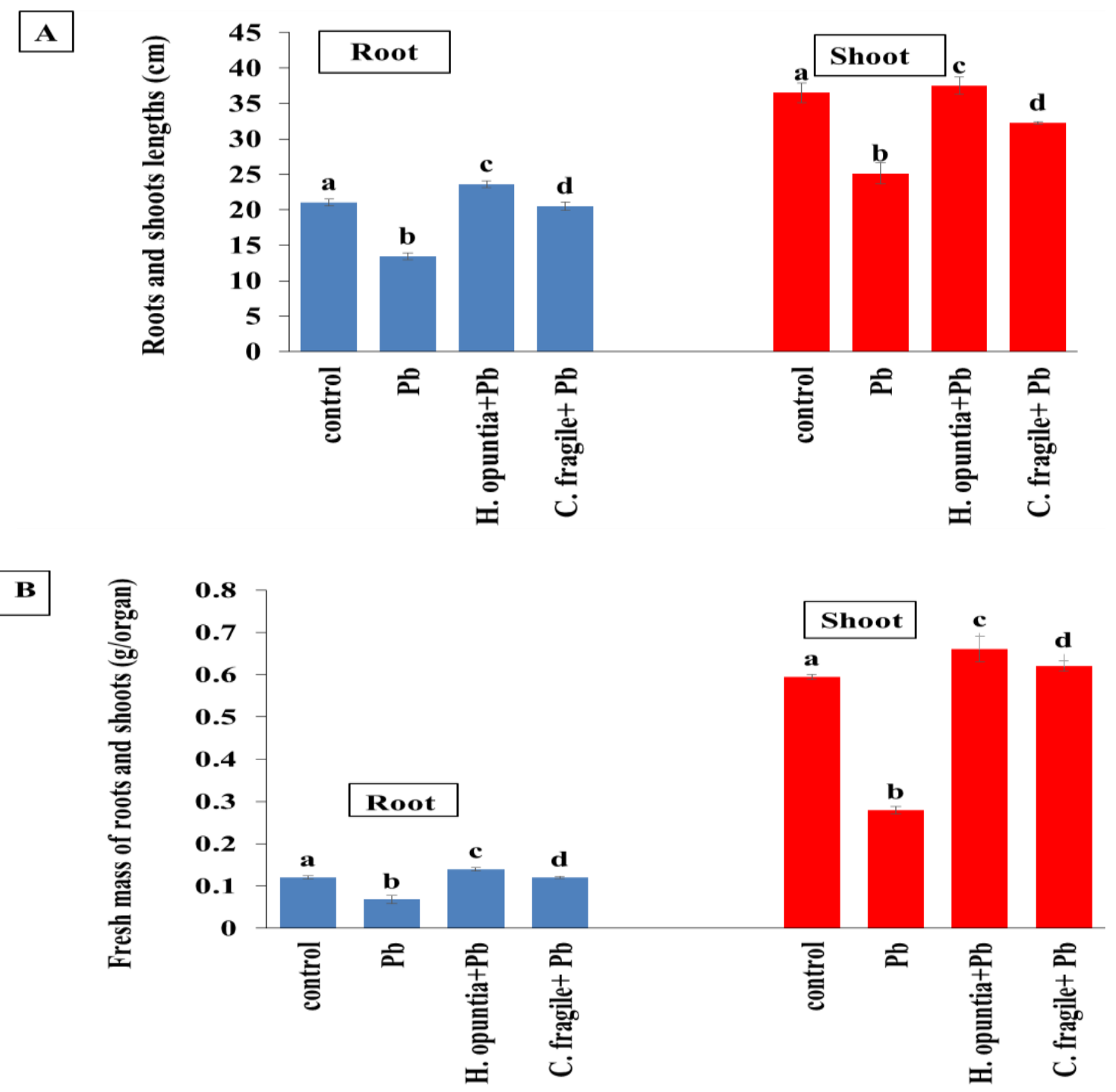


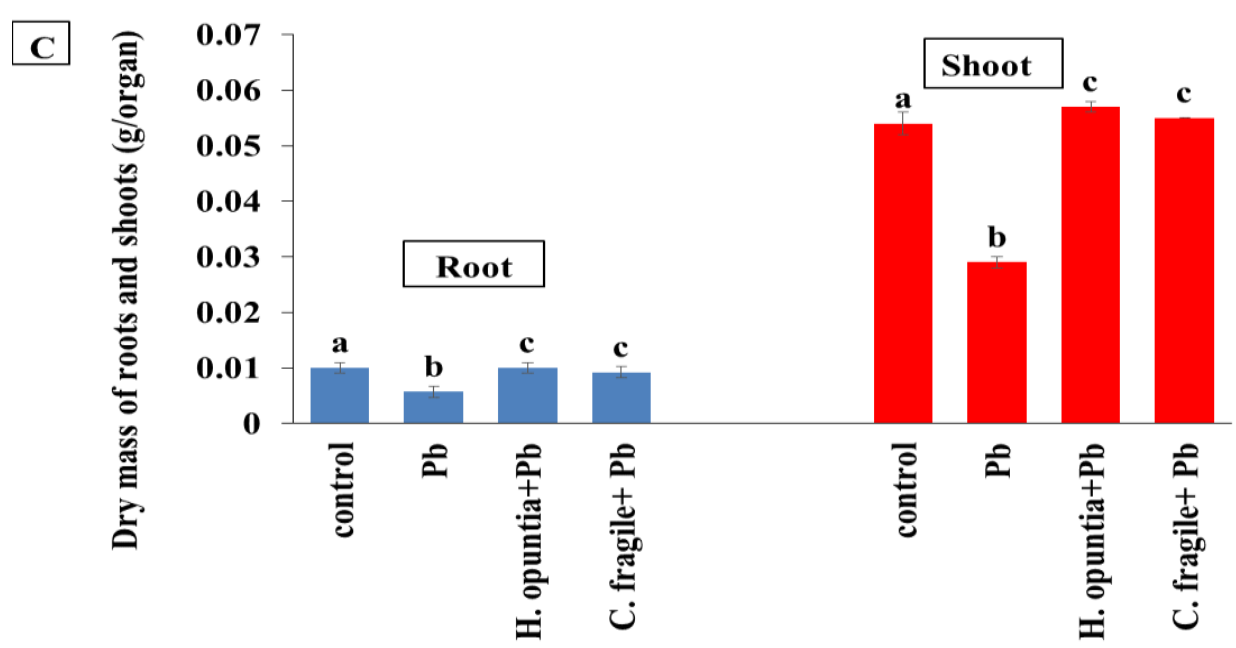

Fig. 1. Effect of seed priming with the aqueous extracts of $H$. opuntia or $C$. fragile for $3 \mathrm{~h}$ on the root length and shoot height (A), fresh mass (B) and dry mass(C) of 21-days old Triticum aestivum plants grown in claysandy soil (1:2 w/w) treated with 400ppm of lead nitrate seven days from sowing. (Bars indicate standard errors between three replicates. Treatments labeled with identical letters are not significant at $P \leq 0.01$ ).

Lead stress caused a highly significant reduction in Chl.a, Chl.b and total chlorophyll (Fig. 2A), where the percentages of decrease were $15.3 \%, 31.1 \%$ and $20.1 \%$, respectively while a highly significant increase in carotenoids (Fig. $2 \mathrm{~B})$ was recorded with a percentage of $20.2 \%$ compared with control value. On the other hand, lead stress led to a significant decrease in photosynthetic activity with $2.4 \%$ decrease relative to the corresponding control values (Fig. $2 \mathrm{C})$. The combined treatments of priming of seeds in H. opuntia or C. fragile aqueous extracts and lead stress indicated a significant amelioration of the harmful effects of lead stress, where Chl.a, Chl.b, total chlorophyll and photosynthetic activity increased compared with the corresponding counterparts under stress. Moreover, priming of wheat seeds by presoaking in $H$. opuntia or $C$. fragile aqueous extracts resulted in a remarkable reduction of carotenoids compared with the corresponding samples under lead stress.

The results represented in Fig. 3 show that lead stress caused a highly significant increase in total soluble sugars content, where the percentages of increase was $29.8 \%$ compared with control. Similarly, priming of $T$. aestivum L. seeds by presoaking in $\mathrm{H}$. opuntia and C. fragile aqueous extracts, and then subjected to lead stress, could increase total soluble sugars content with a percentage $82.6 \%$ and $43.3 \%$, respectively.

Results in Table 3 show that exposure of
T. aestivum seedling to $\mathrm{Pb}$ stress led to the accumulation of $\mathrm{Pb}$ in roots and shoots compared with the control. It was noticed that roots accumulated $\mathrm{Pb}$ more than shoots; while, the two algal extracts decreased the concentration of $\mathrm{Pb}$ in both roots and shoots compared with the stressed plants and the control.

Table 4 reveals that the exposure of wheat to lead stress led to a the reduction in $\mathrm{N}, \mathrm{P}, \mathrm{K}, \mathrm{Mg}$, $\mathrm{Ca}$ and $\mathrm{Cu}$ while $\mathrm{Na}$ and $\mathrm{Fe}$ remarkably increased in both roots and shoots compared with the control. In contrast, the two algal extracts resulted in the increase in $\mathrm{N}, \mathrm{P}, \mathrm{K}, \mathrm{Mg}, \mathrm{Ca}$ and $\mathrm{Cu}$ and a remarkable reduction in $\mathrm{Na}$ and $\mathrm{Fe}$ relative to the stressed plants.

Results in Fig.4A and 4B reveal that lead stress resulted in significant increases in catalase and peroxidase activities, where the percentages of increase were $66.7 \%$ and $80.02 \%$, respectively compared with the control. In contrast, priming of T. aestivum seeds in H. opuntia or C. fragile extracts resulted in great reduction in their activities compared with the control.

Ascorbic acid content increased with $37.9 \%$ compared with the control under lead stress (Fig. 4C). On the other hand, presoaking of T. aestivum seeds in H. opuntia or C. fragile aqueous extracts resulted in a decrease in its content relative to the control. 


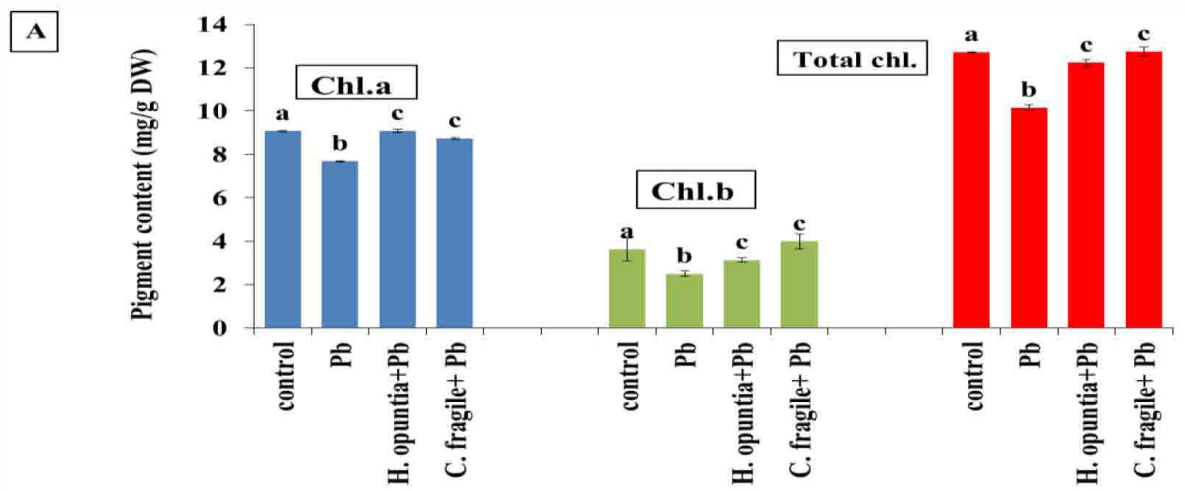

B

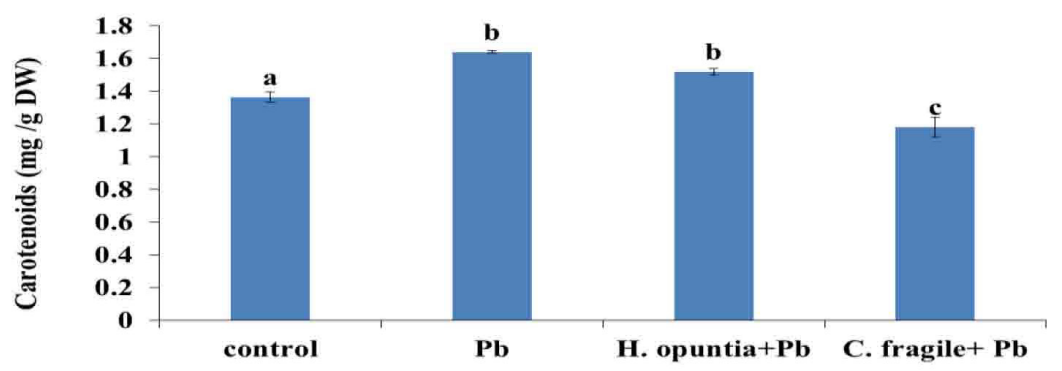

C

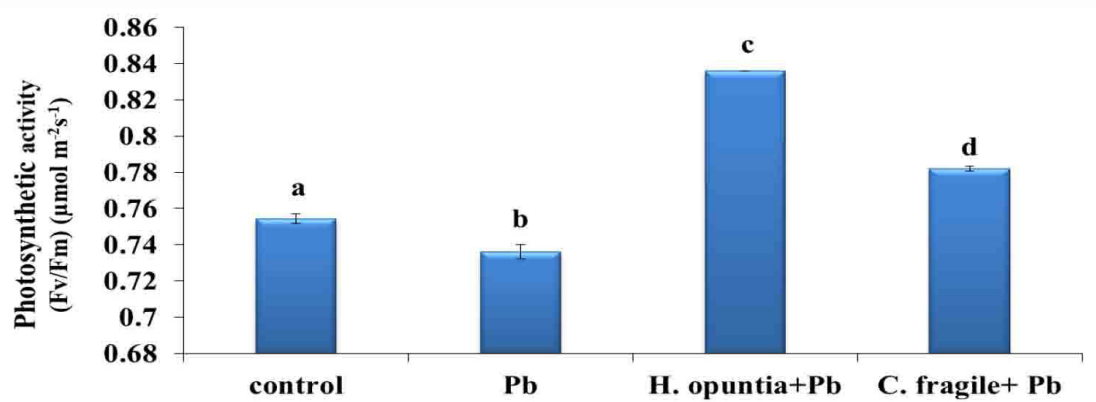

Fig. 2. Effect of seed priming with the aqueous extracts $H$. opuntia or $C$. fragile for $3 \mathrm{~h}$ on Chl.a, Chl.b and total chlorophyll (A), carotenoids (B) and photosynthetic activity (C) of 21-days old Triticum aestivum plants grown in clay-sandy soil $(1: 2 \mathrm{w} / \mathrm{w})$ treated with $400 \mathrm{ppm}$ of lead nitrate seven days from sowing. (Bars indicate standard errors between three replicates. Treatments labeled with identical letters are not significant at $P \leq 0.01$ ).

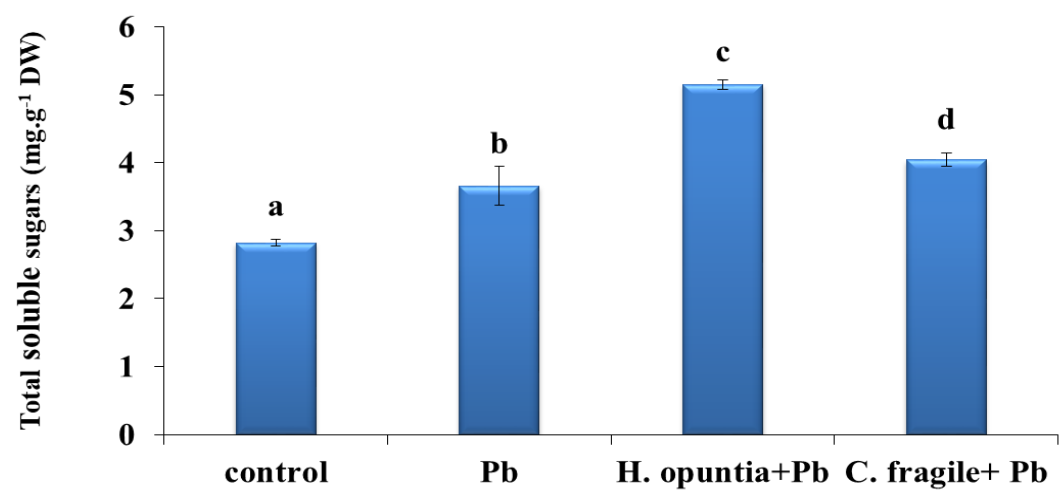

Fig. 3. Effect of seed priming with the aqueous extracts of $H$. opuntia or $C$. fragile for $3 \mathrm{~h}$ on total soluble sugars content of 21-days old Triticum aestivum plants grown in clay-sandy soil (1:2 w/w) treated with 400ppm of lead nitrate seven days from sowing. (Bars indicate standard errors between three replicates. Treatments labeled with identical letters are not significant at $P \leq 0.01$ ). 
TABLE 3. Effect of seed priming with the aqueous extracts of $H$. opuntia or $C$. fragile for $3 \mathrm{~h}$ on lead concentration of 21-days old Triticum aestivum plants grown in clay-sandy soil (1:2 w/w) treated with 400-ppm of lead nitrate seven days from sowing. ( \pm SD 3 replica).

\begin{tabular}{lcccc}
\hline \multirow{2}{*}{$\begin{array}{l}\text { Lead concentration } \\
(\mathbf{m g} / \mathbf{g} \text { DW) }\end{array}$} & Control & Pb stress & $\begin{array}{c}\text { Pb stress after priming } \\
\text { with } \text { H. opuntia }\end{array}$ & $\begin{array}{c}\text { Pb stress after priming } \\
\text { with } \text { C. fragile }\end{array}$ \\
\cline { 2 - 5 } & $0.52 \pm 0.01$ & $3.8 \pm 0.13$ & $0.1 \pm 0.002$ & $0.4 \pm 0.0005$ \\
\hline Roots & $0.1 \pm 0.004$ & $0.23 \pm 0.004$ & $0.02 \pm 0$ & $0.05 \pm 0.003$ \\
Shoots & & & & \\
\hline
\end{tabular}

TABLE 4. Effect of seed priming with the aqueous extracts of $H$. opuntia or $C$. fragile for $3 \mathrm{~h}$ on mineral content of roots and shoots of 21-days old Triticum aestivum plants grown in clay-sandy soil (1:2 w/w) treated with $400 \mathrm{ppm}$ of lead nitrate seven days from sowing. ( \pm SD 3 replica).

\begin{tabular}{|c|c|c|c|c|c|}
\hline \multirow{2}{*}{\multicolumn{2}{|c|}{$\begin{array}{l}\text { Minerals content } \\
\text { (mg/g DW) }\end{array}$}} & \multicolumn{4}{|c|}{ Treatments } \\
\hline & & \multirow{2}{*}{$\begin{array}{c}\text { Control } \\
10.65 \pm 0.52\end{array}$} & \multirow{2}{*}{$\begin{array}{c}\text { Pb stress } \\
6.68 \pm 1.2\end{array}$} & \multirow{2}{*}{$\begin{array}{c}\text { Pb stress after } \\
\text { priming with } \boldsymbol{H} \text {. } \\
\text { opuntia } \\
9.85 \pm 1.1\end{array}$} & $\begin{array}{c}\text { Pb stress after priming } \\
\text { with } C \text {. fragile }\end{array}$ \\
\hline & $\mathrm{N}$ & & & & $8.79 \pm 0.98$ \\
\hline & $P$ & $2.6 \pm 0.05$ & $1.2 \pm 0.11$ & $2.2 \pm 0.17$ & $2.0 \pm 0.11$ \\
\hline & $\mathrm{K}$ & $21.9 \pm 3.8$ & $18.1 \pm 3.6$ & $20.6 \pm 1.65$ & $19.57 \pm 3.1$ \\
\hline & $\mathrm{Ca}$ & $20.7 \pm 1.3$ & $18.01 \pm 1.57$ & $23.42 \pm 2.43$ & $21.71 \pm 1.56$ \\
\hline & $\mathrm{Mg}$ & $12.37 \pm 1.8$ & $8.39 \pm 0.61$ & $11.54 \pm 0.97$ & $10.35 \pm 0.98$ \\
\hline \multirow[t]{8}{*}{ Roots } & $\mathrm{Na}$ & $0.48 \pm 0.02$ & $0.51 \pm 0.003$ & $0.32 \pm 0.032$ & $0.37 \pm 0.002$ \\
\hline & $\mathrm{Cu}$ & $12.5 \pm 1.2$ & $6.6 \pm 0.65$ & $13.7 \pm 0.47$ & $9.95 \pm 1.21$ \\
\hline & $\mathrm{Fe}$ & $1.48 \pm 0.005$ & $2.38 \pm 0.28$ & $1.2 \pm 0.089$ & $1.97 \pm 0.048$ \\
\hline & $\mathrm{N}$ & $9.26 \pm 1.2$ & $7.55 \pm 0.84$ & $8.85 \pm 0.29$ & $8.16 \pm 0.65$ \\
\hline & $\mathrm{O}_{4}$ & $2.6 \pm 0.020$ & $1.9 \pm 0.028$ & $2.4 \pm 0.01$ & $2.2 \pm 0.041$ \\
\hline & $\mathrm{K}$ & $26.7 \pm 2.31$ & $21.6 \pm 1.21$ & $25.83 \pm 0.96$ & $24.75 \pm 3.1$ \\
\hline & $\mathrm{Ca}$ & $22.07 \pm 1.45$ & $15.72 \pm 0.34$ & $20.53 \pm 1.1$ & $19.87 \pm 2.4$ \\
\hline & $\mathrm{Mg}$ & $16.53 \pm 0.73$ & $12.11 \pm 0.65$ & $15.85 \pm 0.78$ & $13.97 \pm 0.97$ \\
\hline \multirow[t]{3}{*}{ Shoots } & $\mathrm{Na}$ & $0.083 \pm 0.005$ & $0.125 \pm 0.006$ & $0.097 \pm 0.002$ & $0.107 \pm 0.005$ \\
\hline & $\mathrm{Cu}$ & $7.2 \pm 0.71$ & $13.2 \pm 1.23$ & $8.73 \pm 0.67$ & $9.38 \pm 0.56$ \\
\hline & $\mathrm{Fe}$ & $0.135 \pm 0.003$ & $0.29 \pm 0.006$ & $0.115 \pm 0.001$ & $0.130 \pm 0.002$ \\
\hline
\end{tabular}



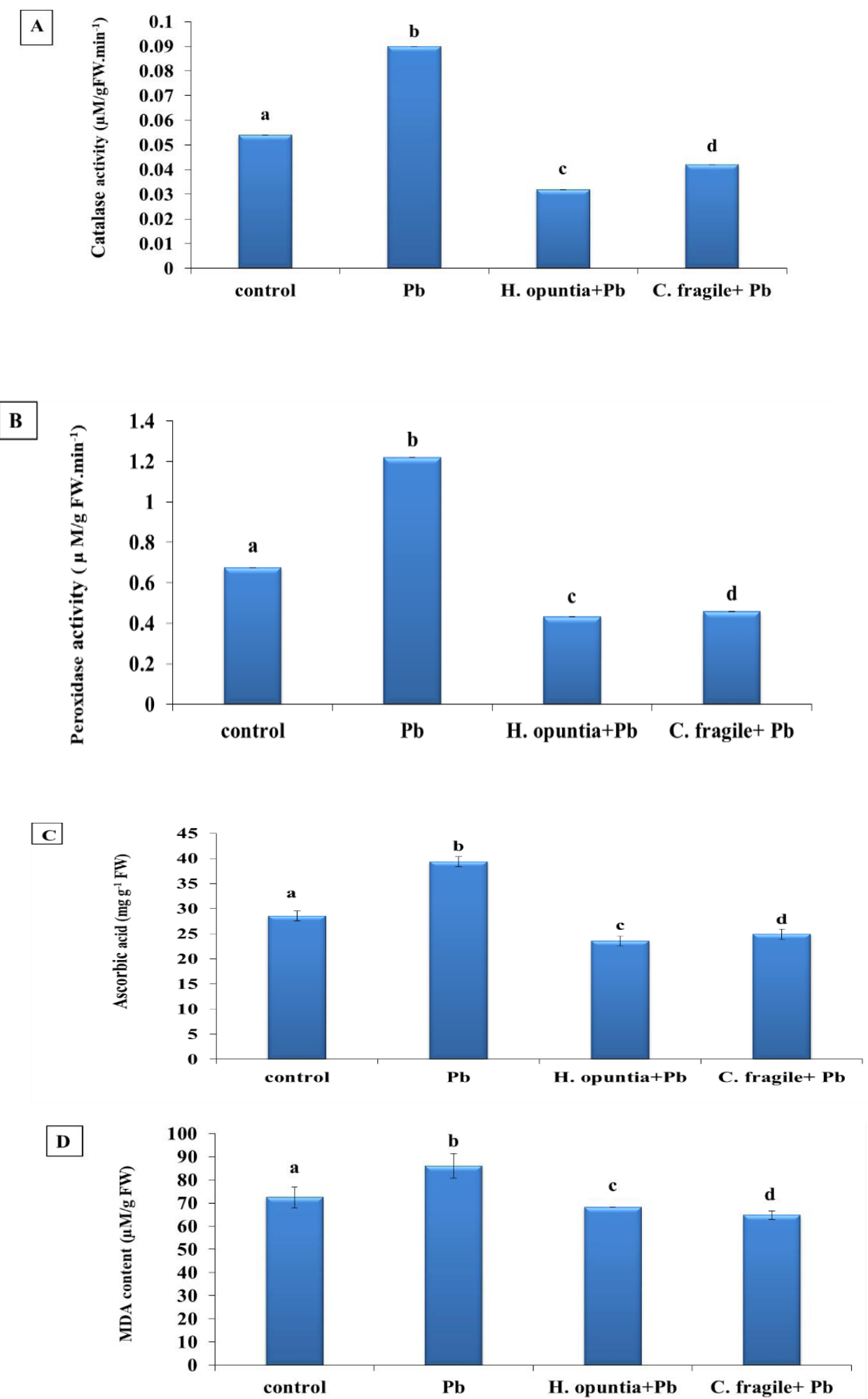

Fig. 4. Effect of seed priming with the aqueous extracts of $H$. opuntia or $C$. fragile for $3 \mathrm{~h}$ on catalase and peroxidase activities (A and B), Ascorbate (C) and malondialdehyde (MDA) (D) contents of 21-days old Triticum aestivum plants grown in clay-sandy soil $(1: 2 \mathrm{w} / \mathrm{w})$ treated with $400 \mathrm{ppm}$ of lead nitrate seven days from sowing. (Bars indicate standard errors between three replicates. Treatments labeled with identical letters are not significant at $\mathrm{P} \leq \mathbf{0 . 0 1}$ ). 
Figure 4D, showed that malondialdehyde (MDA) content significantly increased in the stressed plants with a percentage $9.8 \%$ relative to the control. Priming of T. aestivum seeds with extracts of $H$. opuntia or $C$. fragile decreased the MDA content decreased compared with the control.

\section{Discussion}

Lead stress led to a highly significant reduction in all growth parameters, chlorophyll content and some mineral nutrients $(\mathrm{N}, \mathrm{P}, \mathrm{K}, \mathrm{Mg}, \mathrm{Ca}$ and $\mathrm{Cu}$ ) of wheat plants. The decline in wheat growth may be attributed to nutrient metabolic disturbance or stimulation of indole-3-acetic acid (IAA) oxidation (Pourrut et al., 2011). The inhibition in chlorophyll content and photosynthetic activity may be due to impaired uptake of essential elements such as $\mathrm{Mg}$ and $\mathrm{Fe}$ and substitution of divalent cations by lead, inhibition of Calvin cycle enzymatic catalysis and increased chlorophyllase activity (Cenkci et al., 2010). The reduction of photosynthetic activity in wheat was confirmed by reduced photochemical efficiency of PSII (Fv/Fm). This result was in accordance with those of Kaur et al. (2012). In contrast, lead stress caused an increase in carotenoids that may be a strategy adopted by plants to alleviate the toxic effects of free radicals generated under lead toxicity. The reduction in the mentioned mineral elements is due to the ability of $\mathrm{Pb}$ to block the access of many ions to their absorption sites on the roots, thus inhibiting their uptake. They probably also result from additional ion leakage from the plants (Nareshkumar et al., 2014).

Lead stress caused a highly significant increase in total soluble sugars. These results were in harmony with those of John et al. (2008). The increase in soluble sugars content may be due to the protection of the cell under stress by balancing the osmotic strength of the cytosol with that of the vacuole and the external environment or due to the failure of the plant to hydrolyze carbohydrates or de-novo synthesis of enhanced carbohydrates under $\mathrm{Pb}$-stress.

The recorded results showed that exposure of wheat to $\mathrm{Pb}$ stress led to an accumulation of $\mathrm{Pb}$ in roots and shoots. The majority of absorbed lead accumulated in roots and only a small fraction translocated to shoots due to immobilization by negatively charged pectin within the cell, precipitation of insoluble lead salts in intercellular spaces or accumulation in plasma membranes (Jiang \& Liu, 2010).

In the present study, lead stress led to a significant increase in ascorbic acid, MDA and the activities of catalase and peroxidase in wheat. These results are in conformity with those of Keser \& Saygideger (2010). The increase in Ascorbate could be due to a transient loss in antioxidative capacity and stimulation of oxidant producing enzymes. Therefore, ascorbate acts as a signaling molecule triggering secondary defenses. Enhanced MDA content indicated lipid peroxidation by decreasing the level of saturated fatty acids as well as increasing the unsaturated fatty acid content of membranes in plant. The increase in peroxidase activity to enable the plants to protect themselves against oxidative stress (Tanyolaç et al., 2007). In addition, the increase in CAT activity could be due to an increase in its substrate to maintain the level of $\mathrm{H}_{2} \mathrm{O}_{2}$ as an adaptive mechanism of the plants (Shu et al., 2011).

The ameliorative effect of priming wheat seeds with the extracts of $H$. opuntia and $C$. fragile was reflected in the enhancement of all growth parameters, Chl.a, Chl.b, minerals $(\mathrm{N}$, $\mathrm{P}, \mathrm{K}, \mathrm{Mg}, \mathrm{Ca}$ and $\mathrm{Cu}$ ) and total soluble sugars. The remarkable increase in growth may be due to the presence of three main phytohormones (Table 1) that are auxins (IAA), cytokinins and gibberellins. These hormones can initiate seed germination, growth regulation, breaking bud dormancy and are involved in plant tolerance to a biotic stresses (Tuhy et al., 2013). The increase in chlorophyll content may result from a reduction in chlorophyll degradation that caused by betaines in the seaweed extracts that delay the loss of photosynthetic activity by inhibiting chlorophyll degradation (Khan et al., 2009). Interestingly, $\mathrm{Mg}$ and $\mathrm{Ca}$ in the utilized algal extracts (Table 2) $\mathrm{Mg}$ is involved in the modulation of the activity of key photosynthetic enzyme, ribulose-1, 5-bisphosphate carboxylase/oxygenase (Rubisco) (Engels et al., 2012). While, Ca can prevent cell membrane injury under stressful environmental conditions (Mohamed \& Akladious, 2014). Therefore, the increase in total soluble sugars is a net result of increasing in photosynthetic pigments and due to the presence of $\mathrm{P}$ and $\mathrm{K}$ that are important elements in the biosynthesis and translocation of carbohydrates. 
The reduction recorded in antioxidant compounds, activities of antioxidant enzymes and malondialdehyde(MDA) content with algal extracts could be due to the presence of cytokinin (Table 1) that can inhibit activity of free radical groups, including hydrogen peroxide and superoxide. Furthermore, the presence of $\mathrm{Zn}$ (Table 2) has a positive effect on the antioxidant enzymes activity due to its ability to inhibit NADPH oxidation and oxygen centered free radical generation that improve the antioxidant defense system of the plant and membrane integrity.

\section{Conclusion}

It seems that the current study suggest that presoaking the seeds of Triticum aestivum in the aqueous extracts of $H$. opuntia or $C$. fragile can alleviate the harmful effects of lead stress on Triticum aestivum crop as well as stimulate the plants' growth.

\section{References}

Abbott, L.A. and Hollenberg. L.G. (1976) "Marine Algae of California Stanford". University Press, Stanford, California, USA.

Abdalla, M.M. and El-Khoshiban, N. (2012) The palliative effect of bio-organic fertilizer on lead pollution in Lycopersicum esculentum plants. Proc. $13^{\text {th }}$ international Conference of Agronomy, Faculty of Agriculture, Benha University, Egypt, 9-10 September 2012.

Aleem, A.A. (1978) Contributions to the study of the marine algae of the Red Sea. III- Marine algae from Obhor, in the vicinity of Jeddah, Saudi Arabia. Bulletin, Faculty of Science, King Abdul Aziz University, Jeddah, 2, 99-118.

Allen, S., Grimshaw, H.M., Parkinson, J.A. and Quarmby, C. (1974) "Chemical Analysis of Ecological Materials". Oxford: Blackwell, pp.521.

Anisimov, M.M. and Chaikina, E.L. (2014) Effect of seaweed extracts on the growth of seedling roots of soybean (Glycine max (L.) Merr.) seasonal changes in the activity. International Journal of Current Research and Academic Review, 2(3), 19-23.

Anisimov, M.M., Chaikina, E.L., Klykov, A.G. and Rasskazov, V.A. (2013) Effect of seaweeds extracts on the growth of seedling roots of buckwheat
(Fagopyrum esculentum Moench) is depended on the season of algae collection. Agricultural Science Developments, 2(8), 67-75.

Cenkci, S., Cigerci, I.H., Yildiz, M., Özay, C., Bozdag, A. and Terzi, H. (2010) Lead contamination reduces chlorophyll biosynthesis and genomic template stability in Brassica rapa L. Environmental and Experimental Botany, 67(3), 467-473.

Dubois, M., Gilles, K.A., Hamilton, J.K., Rebers, P.A. and Smith, F. (1956) Colorimetric method for determination of sugars and related substances. Analytical Chemistry, 28(3), 350-356.

Engels, C., Kirkby, E. and White, P.J. (2012) Mineral nutrition, yield and source-sink relationships. In: "Mineral Nutrition of Higher Plants". Marschner P. (Ed.), pp. 85-131, $3^{\text {rd }}$ ed. Academic Press, Elsevier.

FAOSTAT Food and Agriculture Organization of the United Nations (FAO) (2016). Statistical databases.

Heath, R.L. and Packer, L. (1968). Photoperoxidation in isolated chloroplasts. I. Kinetics and stoichiometry of fatty acid peroxidation. Archives of Biochemistry and Biophysics, 125(1), 189-198.

Jiang, W. and Liu, D. (2010) Pb-induced cellular defense system in the root meristematic cells of Allium sativum L. BMC Plant Biology, 10,40-40.

John, R., Ahmed, P., Gadgil, K. and Sharma, S. (2008) Effect of cadmium and lead on growth biochemical parameters and uptake in Lemna polyrrhiza L. Plant Soil and Environment, 54(6), 262-270.

Karanatsidis, G. and Berova, M. (2009) Effect of organic-N fertilizer on growth and some physiological parameters in pepper plants (Capsicum annum L.). Biotechnology and Biotechnological Equipment, 23, 254-257.

Kato, M. and Shimizu, S. (1987) Chlorophyll metabolism in higher plants. VII- Chlorophyll degradation in senescing tobacco leaves; phenolic-dependent peroxidative degradation. Cand.J. Bot. 65, 729-735.

Kaur, G., Singh, H.P., Batish, D.R. and Kohli, R.K. (2012) Growth, photosynthetic activity and oxidative stress in wheat (Triticum aestivum) after exposure of lead to soil. Journal of Environmental Biology, 33, 265-269. 
Keser, G. and Saygideger, S. (2010) Effects of Pb on the activities of antioxidant enzymes in watercress, Nasturtium officinale. $R \mathrm{Br}$. Biological Trace Element Research, 137, 235-243.

Khan, W., Rayirath, U.P., Subramanian, S., Jithesh, M.N., Rayorath, P., Hodges, D.M., Critchley, A.T., Craigie, J.S., Norrie, J. and Balakrishan, P. (2009) Seaweed extracts as biostimulants of plant growth and development. Journal of Plant Growth Regulation, 28, 386-399.

Kumari, R., Kaur, I. and Bhatnagar, A.K. (2011) Effect of aqueous extract of Sargassum johnstonii Setchel \& Gardner on growth, yield and quality of Lycopersicon esculentum Mill. Journal of Applied Phycology, 23, 623-633.

Maccaferri, M., Sanguineti, M.C., Giuliani, S. and Tuberosa, R. (2009) Genomics of tolerance to abiotic stress in the Triticeae. In: "Plant Genetics and Genomics: Crops and Models, 1, Genetics and Genomics of the Triticeae". Feuillet, C. and Muehlbauer, G.J. (Ed.), pp. 481-558, 7. Springer, New York, .

Metzner, H., Rou, H. and Senger, H. (1965) Unter suchungen zur synchronisier barkeit ein zeiner pigment. Mangol Mutanten von chlorella. Planta, 65, 186.

Mohamed, H.I. and Akladious, S.A. (2014) Influence of garlic extract on enzymatic and non- enzymatic antioxidants in soybean plants (Glycine Max) grown under drought stress. Life Science Journal, 11(3s), 46-58.

Nareshkumar, A., Krishnappa, B.V., Kirankumar, T.V., Kiranmai, K., Lokesh, U., Sudhakarbabu, O. and Sudhakar, C. (2014) Effect of Pb-stress on growth and mineral status of two groundnut (Arachis hypogaea L.) cultivars. Journal of Plant Sciences, 2(6), 304-310.
Oser, B. (1979) “Hawk's Physiological Chemistry", $15^{\text {th }}$ ed., McGrow Hill Publish. Company, New York.

Pourrut, B., Shahid, M., Dumat, C., Peter Winterton, P. and Pinelli, E. (2011) Lead uptake, toxicity, and detoxification in plants. Reviews of Environmental Contamination and Toxicology, 213, 113-136.

Shindy, W.W. and Smith, O.E. (1975) Identification of plant hormones from cotton ovules. Plant Physiology, 55, 550-554.

Shu, X., Yin, L., Zhang, Q. and Wang, W. (2011) Effect of $\mathrm{Pb}$ toxicity on leaf growth, antioxidant enzyme activities and photosynthesis in cuttings and seedlings of Jatropha curcas L. Environmental Science Pollution Research International, 19(3), 893-902.

Tanyolaç, D., Ekmekçi, Y. and Ünalan, S. (2007) Changes in photochemical and antioxidant enzyme activities in maize (Zea mays L.) leaves exposed to excess copper. Chemosphere, 67, 89-98.

Taylor, W.S. (1985) "Marine Algae of the Eastern Tropical and Sub-trobical Coasts of Americas". ANN. Arbor the University of Michigan Press.

Tuhy, L., Chowanska, J. and Chojnacka, K. (2013) Seaweed extracts as bio-stimulants of plant growth: A review. Chemik, 67(7), 636-641.

Yassen, A.A., Badran, N.M. and Zaghloul, S.M. (2007) Role of some organic residues as tools for reducing metals hazard in plant. World Journal of Agricultural Sciences, 3(2), 204-209.

Received 19/2/2018; accepted 25/3/2018) 
تخفيف الإجهاد بعنصر الرصاص في نبات القمح بإستخدام نقع البذرة في المستخلصات

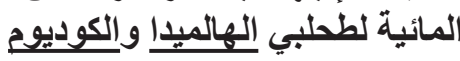

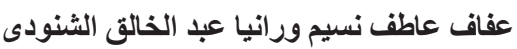
قسم النبات ـ كلية العلوم - جامعة طنطا ـ طنطا ـ مصرى.

تهدف الدر اسة الحالية إلى تقييم التأثير ات الضارة للإجهاد بعنصر الرصاص على نبات القمح (صنف جميز الكيا

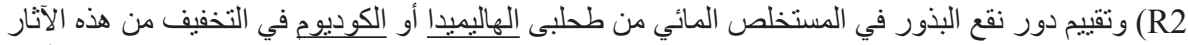

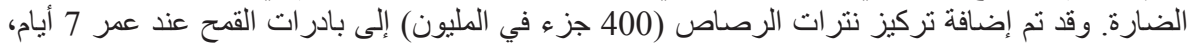

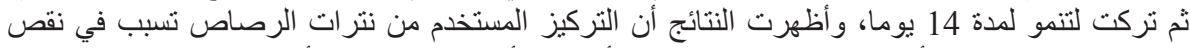

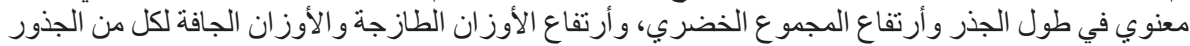

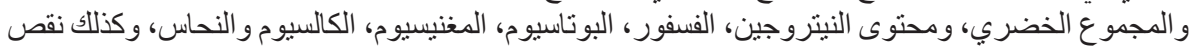

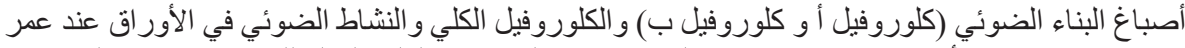

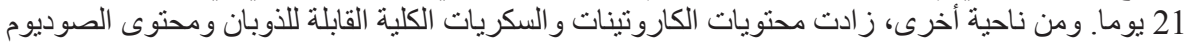

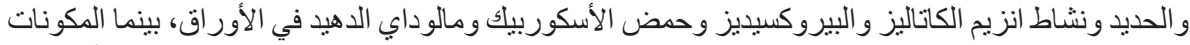

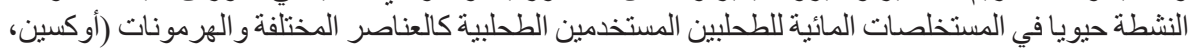

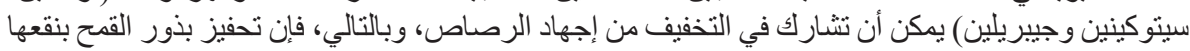

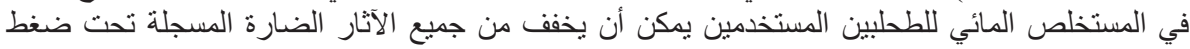

